\title{
High-resolution crustal structure of the Yinchuan basin revealed by deep seismic reflection profiling: implications for deep processes of basin
}

\author{
Xingfu Huang $\cdot$ Shaoying Feng $\cdot$ Rui Gao $\cdot$ Wenhui Li
}

Received: 14 September 2015/ Accepted: 2 March 2016/Published online: 26 April 2016

(C) The Author(s) 2016. This article is published with open access at Springerlink.com

\begin{abstract}
The Yinchuan basin, located on the western margin of the Ordos block, has the characteristics of an active continental rift. A NW-striking deep seismic reflection profile across the center of Yinchuan basin precisely revealed the fine structure of the crust. The images showed that the crust in the Yinchuan basin was characterized by vertical stratifications along a detachment located at a two-way travel time (TWT) of $8.0 \mathrm{~s}$. The most outstanding feature of this seismic profile was the almost flat Mohorovičić discontinuity (Moho) and a high-reflection zone in the lower crust. This sub-horizontal Moho conflicts with the general assumption of an uplifted Moho under sedimentary basins and continental rifts, and may indicate the action of different processes at depth during the evolution of sedimentary basins or rifts. We present a possible interpretation of these deep processes and the sub-horizontal Moho. The high-reflection zone, which consists of sheets of high-density, mantlederived materials, may have compensated for crustal thinning in the Yinchuan basin, leading to the formation of a sub-horizontal Moho. These high-density materials may have been emplaced by underplating with mantlesourced magma.
\end{abstract}

\section{Huang · R. Gao $\cdot$ W. Li}

Key Laboratory of Earthprobe and Dynamics, MLR, Institute of Geology, Chinese Academy of Geological Sciences, Beijing, China

e-mail: huangxfpj@163.com

S. Feng $(\bowtie)$

Geophysical Exploration of China Earthquake Administration,

Zhengzhou, China

e-mail: fsy.ny@163.com
Keywords Yinchuan basin - Deep seismic reflection section $\cdot$ Deep process $\cdot$ Magma underplating $\cdot$ Moho

\section{Introduction}

The Yinchuan basin is one of the Cenozoic faulted basins around the Ordos block in China, with Ordos block to its east, bounded by the Alxa block to its west, and contacts with the NE Tibetan arcuate tectonic belt to its South (Fig. 1). The Yinchuan basin is located at the northern end of the N-S trending seismotectonic zone, which has undergone intensive earthquake activities during the modern times, including a great earthquake of magnitude 8.0 in 1730 ( $\mathrm{Li}$ and Wan 1984; Lin et al. 2015). Because of the devastating geologic hazards, previous researchers have conducted a series of investigations of active faults in the Yinchuan basin, and have determined their active timings, patterns, and phases of activity (Zhang et al. 1982; Deng et al. 1984; Liao et al. 2000; Chai et al. 2001, 2006; Lei et al. 2011, 2012).

Geological surveys refer to tectonic landforms in and around the Yinchuan basin (Zhou et al. 1985) and regional tectonic evolution in the Cenozoic (Deng et al. 1999) roughly delineated the formation age and evolution process of the Yinchuan basin. The results, however, were obtained from tectonic stress field inversion (Zhang et al. 1998, 2006; Huang et al. 2013) specifically indicated the stress states in each stage during the evolution process. Geothermochronology evidences got from Zircon, Apatite fission track demonstrated the absolute ages of some evolution stages (Zhao et al. 2007; Liu et al. 2010). Oil exploration in the Yinchuan basin preliminarily revealed the shallow basin structures and features of the Cenozoic strata (PGCGCOF 1992; Hou et al. 2012, 2014). The basic 


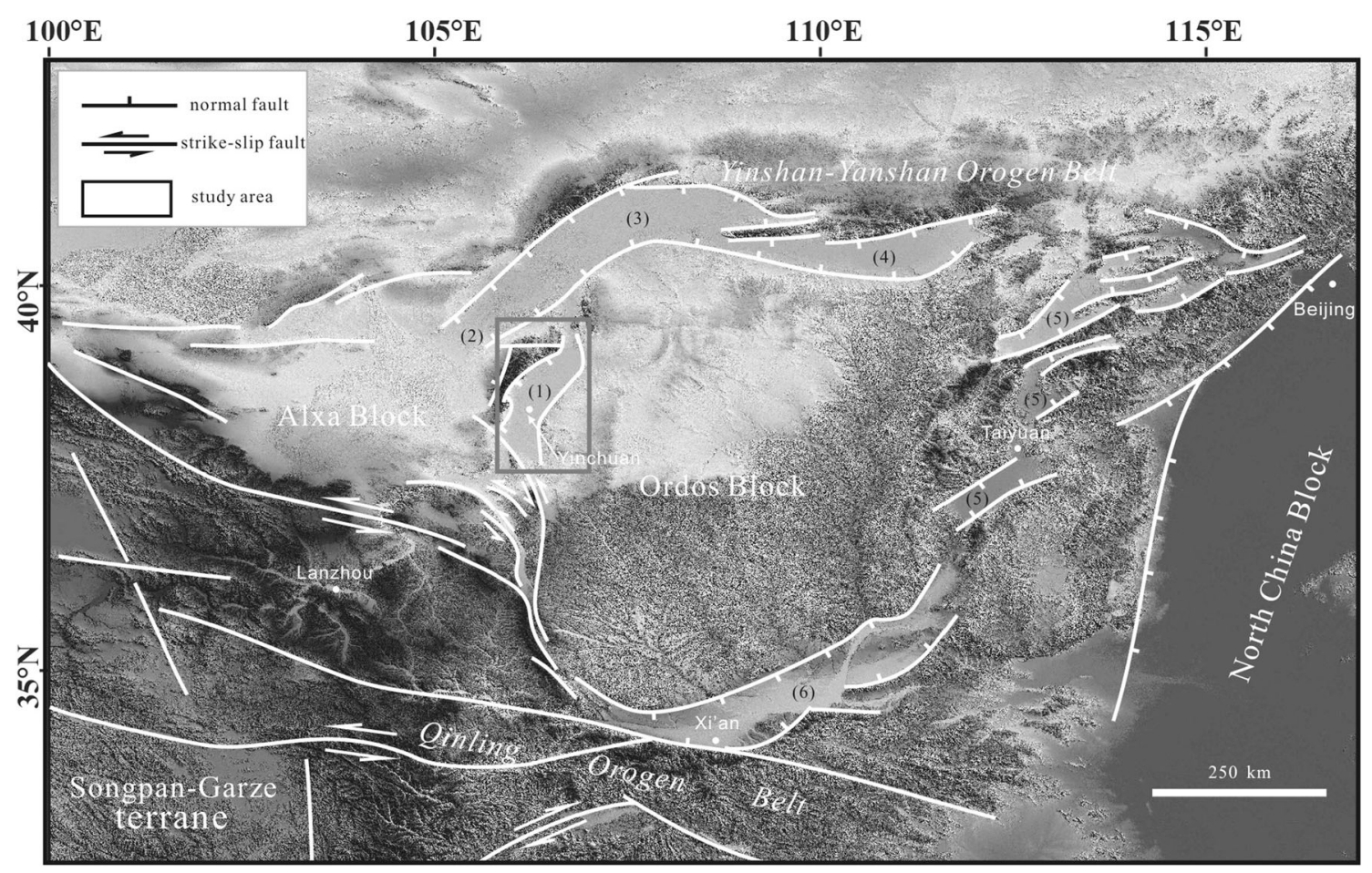

Fig. 1 Digital elevation model (DEM) image showing a simplified structural map of the Yinchuan basin and adjacent area. 1 Yinchuan basin; 2 Bayanhaote basin; 3 Linhe basin; 4 Hohhot-Baotou basin; 5 Shanxi graben system; 6 Weihe basin

tectonic framework has been determined to be an almost symmetrical graben combination which is bounded by Helanshan eastern piedmont fault $\left(F_{2}\right)$, Luhuatai fault $\left(F_{3}\right)$, Yinchuan-Pingluo fault $\left(F_{4}\right)$, and Huanghe fault $\left(F_{5}\right)$ from west to east (Fig. 2).

As mentioned above, most of the earlier studies have concentrated on the surficial deposits of the basin and the shallow geology; investigations of deep geological structure, which is of great significance to understand the geodynamics of basin evolution, are relatively rare, or investigation results are not distinct enough to decipher the deep process of basin evolution. The depth of Mohorovičić discontinuity (Moho) was previously thought to have been uplifted by about $6 \mathrm{~km}$ under the Yinchuan basin compared with the adjacent Ordos block and Alxa block (EBGTSSB 1992). This phenomenon has been widely utilized to explain the deep geodynamics occurring during the evolution of the basin, with the uplifted Moho leading to the crustal thinning that ultimately promoted the formation of Yinchuan basin (Zhou et al. 1985; Deng et al. 1999). Deep seismic reflection profiles are an international recognized technique of revealing the fine structure of the lithosphere and are used to resolve the geology at depth (Wang et al. 2010); furthermore, images obtained from deep seismic reflection profiles are more precise and reliable than other geophysics methods. Nevertheless, a WNW-ESE trending deep seismic reflection profile crossing the Yinchuan basin carried out in 2008 clearly revealed the fine crustal structure of the Yinchuan basin (Fang et al. 2009; Feng et al. 2011) with a distinct reflection Moho that is nearly flattened, which conflicted with previous suggestion of a convex Moho (Fang et al. 2009). Therefore, the deep processes in the Yinchuan basin require a new explanation.

This article, based on a reasonable explanation of this deep seismic reflection profile, combined with previous research results, proposes a new interpretation of the geological processes occurring at depth in the Yinchuan basin. During the basin evolution process, the deep process is featured by mantle-derived magmatic underplating instead of Moho uplift as mentioned in previous works.

\section{Geological setting}

Our seismic profile crosses the center of Yinchuan basin (Fig. 2a), which is crescent-shaped with a width of 40-60 km, a length $>180 \mathrm{~km}$, and is located at the western edge of the Ordos block (Fig. 1). The west side of Yinchuan basin is connected with the Helanshan intracontinental superimposed deformation belt (Huang et al. $2015)$ via the Helanshan eastern piedmont fault $\left(F_{2}\right)$. On the eastern side, the Yinchuan basin is bounded by Huanghe fault $\left(F_{5}\right)$, which separates the Yinchuan basin from the Ordos block. The southwestern boundary of 
a

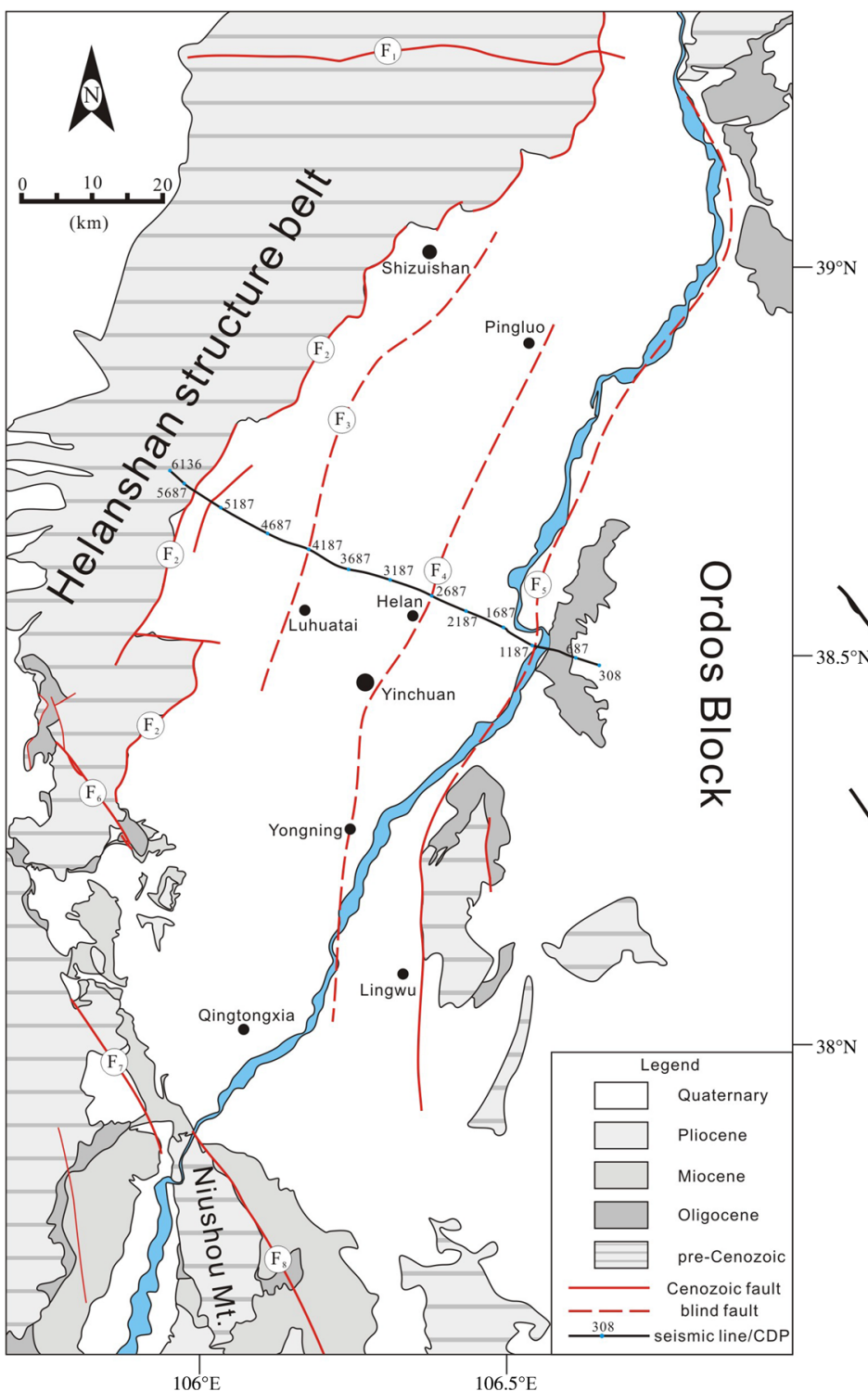

b

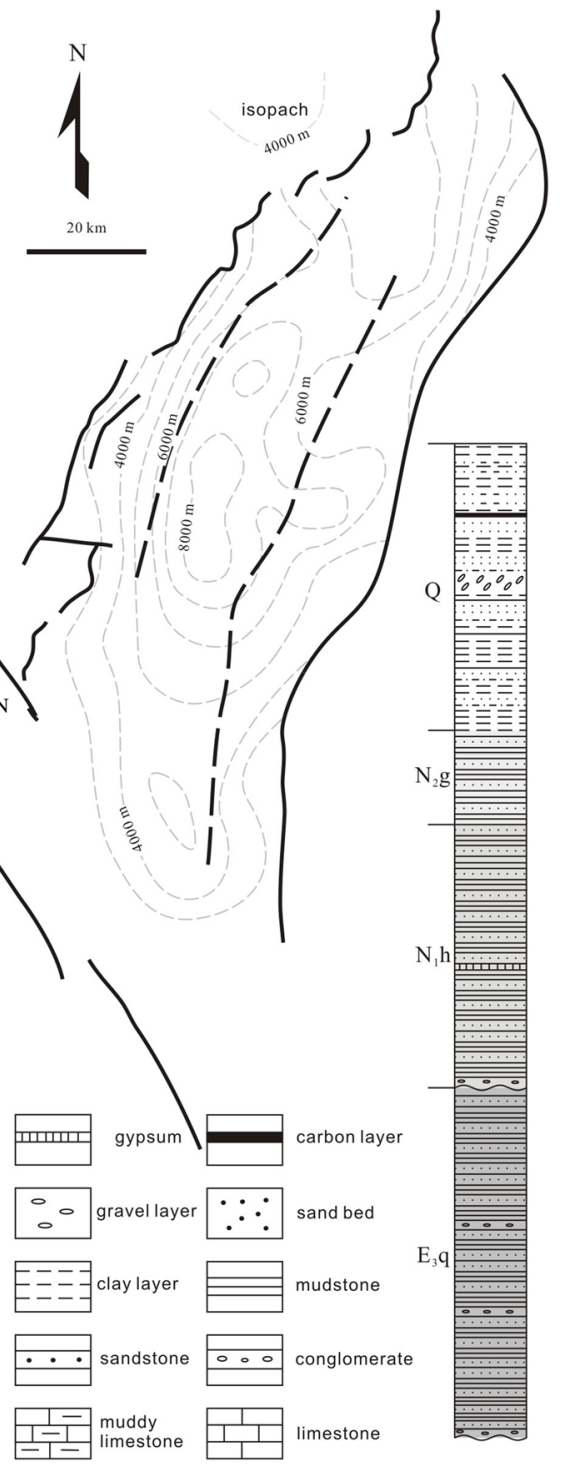

Fig. 2 a Simplified geological map of the Yinchuan basin (modified from 1:200,000 geological maps); b Thickness of deposits (modified from Yang et al. 2009) and depositional sequences in the Yinchuan basin. $F_{1}$ Zhengyiguan fault; $F_{2}$ Helanshan eastern piedmont fault; $F_{3}$ Luhuatai fault; $F_{4}$ Yinchuan-Pingluo fault; $F_{5}$ Huanghe fault; $F_{6}$ Sanguankou fault; $F_{7}$ Gezishan fault; $F_{8}$ Luoshan-Niushoushan fault

Yinchuan basin is limited by a series of Cenozoic faults, such as Sanguankou fault $\left(F_{6}\right)$, Gezishan fault $\left(F_{7}\right)$, and Luoshan-Niushoushan fault $\left(F_{8}\right)$. In addition to these boundary faults, two other key faults-Luhuatai fault $\left(F_{3}\right)$ and Yinchuan-Pingluo fault $\left(F_{4}\right)$-are found in the Yinchuan basin.

The Yinchuan basin is filled with $4000-8000$ m thick Cenozoic sediments (Fig. 2b). The sedimentary center of Yinchuan basin is distributed along the eastern side of Luhuatai fault (F3), almost paralleling to the axis of the basin (Fig. 2b). Cenozoic sediments in the Yinchuan basin could be divided into five series: (1) Oligocene
Qingshuiying formation $\left(\mathrm{E}_{3} \mathrm{q}\right)$, (2) Miocene Hongliugou formation $\left(\mathrm{N}_{1} \mathrm{~h}\right)$, (3) Pliocene Ganhegou formation $\left(\mathrm{N}_{2} \mathrm{~g}\right)$, (4) Pleistocene series, and (5) Holocene series $\left(\mathrm{Q}_{4}\right)$. In addition, the Eocene series Sikouzi Formation possibly exists under the Yinchuan basin (Deng et al. 1999; Zhang et al. 2003b), although recent research has referred to the chronology of Sikouzi formation in Ningnan basin, indicating that this formation occurred after ca. $30 \mathrm{Ma}$ and belongs to the Oligocene (Wang et al. 2011). Furthermore, the Ningnan basin formed earlier than the Yinchuan basin (Zhou et al. 1985), so we assumed that the Oligocene was the earliest formation timing. Previous researchers has 
determined the deposition rate of each phase during basin evolution process with $0.108,0100,0.518$, and $0.615 \mathrm{~mm} / \mathrm{a}$ at Oligocene, Miocene, Pliocene, and Quaternary, respectively (Zhao et al. 2007). Based on these assumptions, the Yinchuan basin is still an actively faulting basin.

\section{Seismic data acquisition and processing}

A total of $69 \mathrm{~km}$ of seismic reflection data were collected across the main faults of Yinchuan basin during the year 2008 (Fig. 2a). The explosion source with a short charge of $24 \mathrm{~kg}$ was used in a single well at a depth of $20-25 \mathrm{~m}$, or of 18-24 kg was used in multiple short arrays at a depth of 7-15 m. SYSTEM-II seismometers of I/O corporations with 480 channels and 48 receiving traces were employed in the survey. Geophone arrays spaced at $25 \mathrm{~m}$ were arranged. The maximum offset is $7500 \mathrm{~m}$, while the minimum offset is $0 \mathrm{~m}$. The recording time is $16 \mathrm{~s}$, with a sampling interval of $2 \mathrm{~m}$.

Data processing adopted the FOCUS processing system. Pre-stacking processing was performed by conducting elevation and refraction static corrections, true-amplitude recovery, surface-consistent amplitude compensation, band-pass filtering, two-dimensional dip filtering, surfaceconsistent de-convolution, velocity analysis, residual static correction, and dip-moveout correction. An iterative procedure was employed to achieve the optimal parameters for stacking and post-stack noise attenuation.

\section{Interpreted seismic reflection profile}

The processed seismic section is shown in Fig. 3 which clearly revealed the fine crustal structure of the Yinchuan basin. And the preliminary interpretation of the seismic section is presented in Fig. 5. As shown in Fig. 5, the crust which is characterized by a distinct vertical stratification could be divided into two parts, i.e. upper crust (UC) and low crust (LC), at about $8.0 \mathrm{~s}$ TWT (two-way travel time) corresponding to a depth of about $20 \mathrm{~km}$. The upper crust could be further split into two segments at $4.0 \mathrm{~s}$ TWT. The segment at $0-4 \mathrm{~s}$ TWT $(0-8 \mathrm{~km}$ in depth) indicates distinct layered strata with a strong reflection energy, excellent continuity of strata, and clear relations of strata group. The deepest reflection horizons were revealed in the

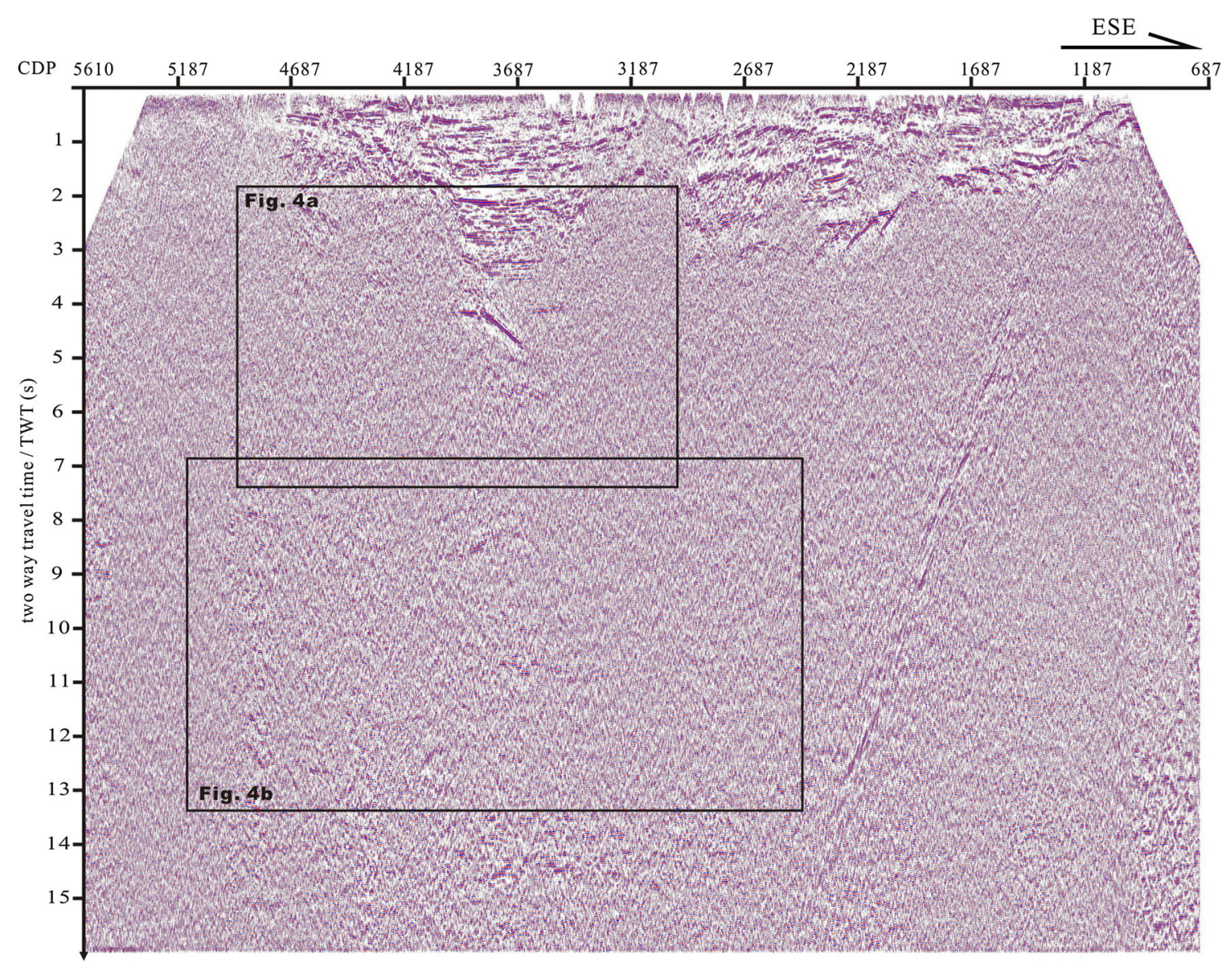

Fig. 3 Deep seismic reflection profile in the Yinchuan basin 


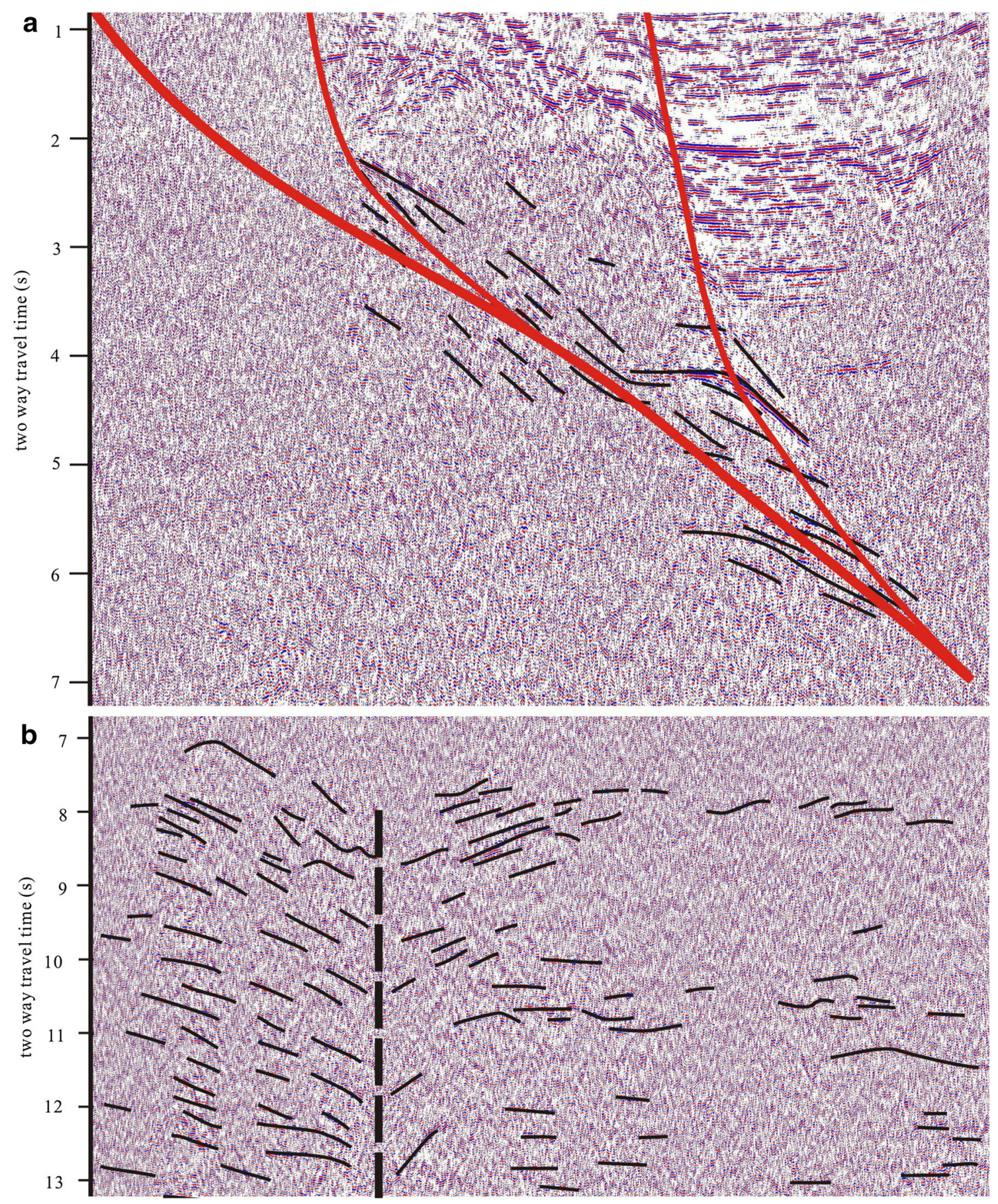

Fig. 4 Detailed reflection features of $R_{1}$ (a) and the lower crust (b) in the Yinchuan basin (see locations in Fig. 3)

center of this seismic line (roughly between CDP 4187 and 2687), and shallowed from the center to both sides (Fig. 5). This is a typical characteristic of sedimentary basin. The segment at 4-8 s TWT (8-20 km in depth) shows almost no reflection, except for two dipping reflection zones, i.e. $R_{1}$ (Fig. $4 \mathrm{a}$ ) and $R_{2}$ (Fig. 5), which are possibly representatives of fracture zone of Helanshan eastern piedmont fault and fracture zone of Huanghe fault, respectively. Lower crust (LC) shows relatively simple reflective features, but could be subdivided at CDP 4187 (thick dashed line) into two parts in east-west strike on the seismic section according to the reflection features (Figs. 4b, 5). The west segment is characterized by a pervasive distribution of a series of short, dipping events from 8.0 to $13.0 \mathrm{~s}$ TWT, whereas the east section shows three reflection interfaces roughly located at 8.0,11.0, and $13.0 \mathrm{~s}$ 


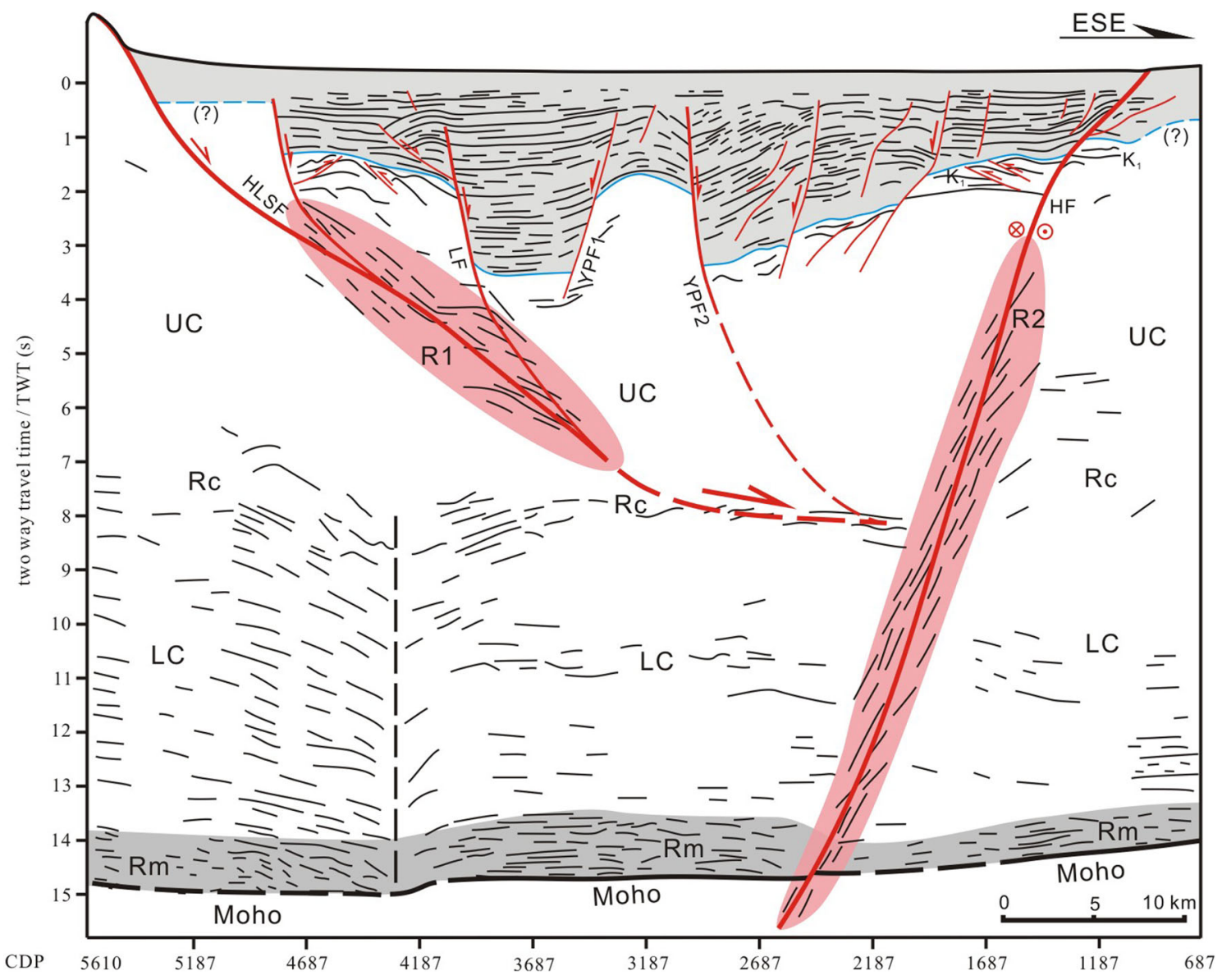

Fig. 5 Line drawing derived from the prominent reflections of the stack section and interpretation results of the Yinchuan basin from deep seismic reflection profiling. $U C$ upper crust; $L C$ low crust; $H L S F\left(F_{2}\right)$ Helanshan eastern piedmont fault; $L F\left(F_{3}\right)$ Luhuatai fault; $Y P F 1\left(F_{4}\right) / 2$ Yinchuan-Pingluo fault $1 / 2 ; H F\left(F_{5}\right)$ Huanghe fault; $R_{c}$ boundary of upper crust and low crust; $R_{m}$ high reflection zone

TWT with no distinct reflection among these interfaces (Fig. 4b). This feature may be representative of two different crystalline basements under the Yinchuan basin.

The Moho, which is distinguished by a thick high reflection zone from 14 to $15 \mathrm{~s}$ TWT (42-43 km in depth), manifests as a nearly flattened geometric characteristic (Fig. 5). The high reflection zone consists of a series of horizontal, layered, intensive reflection events with continuing $0.6-1 \mathrm{~s}$ TWT. Adopting $6.4 \mathrm{~km} / \mathrm{s}$ as the wave velocity of this zone (Feng 2011), this high reflection zone represents 2-3.2 km thickness of the lower crust zone, and the thickness decreases with the decreasing of the sediment thickness in Yinchuan basin (Fig. 5). The almost flattened Moho and high reflection zone existing here come into sharp conflict with general thought that the sedimentary basins possess an uplifted Moho. So we should pay special attention to this phenomenon, and this would be detailedly interpreted in the next section.

\section{Discussion}

Continental rift zones are long, narrow tectonic depressions in the Earth's surface where the entire lithosphere has been modified in extension (Olesen 1995). Conventional models of rift zones include three characteristic features: (1) a surface manifestation as an elongated topographic trough, (2) Moho shallowing due to crustal thinning, and (3) reduced seismic velocity in the uppermost mantle due to decompression melting or heating from the Earth's interior (McKenzie 1978; Ruppel 1995). Many Cenozoic continental rifts do not have all three of these characteristics mentioned above-for example, only the surface manifestation can be observed in the Baikal rift zone and the crust and mantle characteristics are not seen (Nielsen and Thybo 2009; Thybo and Nielsen 2009). A model of the seismic compressional velocity along the seismic profile across the south Kenya rift indicated that the Moho is nearly flatten, 
unlike with previous models (Thybo et al. 2000). Studies in the south Rhine rift graben have again confirmed a flat Moho (Brun et al. 1992). But a common feature requiring to be paid special attention is a zone of high seismic velocity or high reflection zone at the bottom of lower crust (Thybo and Artemieva 2013). The factors related to formation of this feature were speculated as the result of magmatic underplating (Thybo and Artemieva 2013), a process induced by mantle-derived magma intrusion into the lower crust in the form of sheets. Achievements of experimental simulation have confirmed that mantlederived magma could intrude into the lower crust in the form of sheets (Deemer and Hurich 1994; Gerya and Burg 2007). So the expected Moho uplift under the continental rifts may be compensated by the high-density materials deriving from mantle by magmatic underplating, resulting in the observed high-velocity zones or high reflection zones (Thybo and Artemieva 2013).

The Cenozoic Yinchuan basin is a long, narrow tectonic depression at the west Ordos block. Meanwhile, the entire lithosphere of the Yinchuan basin is in the NW-SE extension stress field (Chen et al. 2009, 2010; Ma et al. 2010). These two characteristics are consistent with the definition of a rift basin given by Olesen (1995). In addition, there are still strong, active tectonics in the Yinchuan basin and a relatively high rate of deposition. We therefore proposed that Yinchuan basin is a Cenozoic depression with the characteristics of an active continental rifts. As revealed by seismic profile, the Moho under Yinchuan basin shows a flattened geometry. However, a high reflection zone with 2-3.2 km thickness could be observed in the lower crust of Yinchuan basin (Fig. 5). The thickness of this high reflection zone corresponds to the suggestion of McCarthy and Parsons (1994) that the thickness of layered magmatic intrusion results from magmatic underplating no more than $4 \mathrm{~km}$. We therefore speculated that the formation of high reflection zone under the Yinchuan basin was attributed to magmatic underplating, by comparing this reflection zone with other zones typical of underplating.

We rarely know about material compositions of this high reflection zone, because of the untouched depth and absence of magmatic rock with information about deep earth in the surface. However, we can glimpse some clues about the material composition of the high reflection zone by comparing with typical rift zones. Typical continental rifts, such as Baikal rifts, Kenya rifts, and Rhine rift graben, have been shown to have high-reflection zones consisting of mantle-derived ultramafic and mafic magmatic rocks intruded by magmatic underplating (Thybo and Artemieva 2013). Detailed petrographic study about gabbro xenoliths sourced from crust-mantle boundary (high reflection zone in seismic profile) in the south basin and range province demonstrated that the mantle-sourced materials which intruded into the lower crust formed the 2-km-thick high reflection zone (McGuire 1994). The 3 -km-thick high reflection zone in the Su-Lu area of China possibly consists of peridotite and mafic granulite by underplating during the Eocene period (Yang and Wang 2002). This kind of high reflection zones in the lower crust are pervasively revealed by seismic reflection section in the middle and lower reaches of the Yangtze river, and possibly consist of ultramafic-mafic magmatic rocks by underplating (Lv et al. 2004, 2005). Meanwhile, magmatic underplating occurred in Mesozoic in North China was considered to be the result of mantle-sourced mafic magma intruded into the lower crust (Liu et al. 2004). We are therefore more inclined to assume that the compositions of the high reflection zone in the Yinchuan basin consist of mantle-derived mafic sheets, but this could not be confirmed without more detailed petrographic information.

The precise formation timing of this high reflection zone in Yinchuan basin is difficult to obtain in the absence of related surface magmatic rocks that could be used for dating. Only a relative chronology could be speculated from some indirect evidences in the periphery of Yinchuan basin. As we can see in Fig. 5, Huanghe fault slightly offset the Moho and high reflection zone $\left(R_{\mathrm{m}}\right)$. The fact that the Huanghe fault formed in Oligocene can be deduced from strata outcropping on both sides of Huanghe fault. So the high reflection zone formed earlier than Oligocene. The fine crustal structure of Hohhot-Baotou basin, which is part of the same fault basin around the Ordos block, has also been examined by deep seismic reflection profiling (Feng et al. 2015). These result shows similar reflection features to those in the Yinchuan basin, for example, the deepest Moho is seen under the deposition center without uplift, the thickness of the high-reflection zone decreases from deposition center to both sides, and both Moho and high reflection zone are offset by Cenozoic basin-controlling boundary fault. All these characteristics indicate that both the Yinchuan basin and the Hohhot-Baotou basin experienced similar deep processes. In addition, this seismic profile is near areas where there are large numbers of outcrops of Cenozoic basalts. Xenoliths included in these basalts indicated that magmatic underplating occurred in the lower crust of these areas during Late Mesozoic (158-97 Ma) (Liu et al. 2004). In addition, a great quantity of Late Yanshanian gabbros were detected under the Bayanhaote basin separated only by a mountain range from the Yinchuan basin (Zhang et al. 2003a), implying that a deep magmatic event occurred during this time. Based on this analysis, we suggest that magmatic underplating during the Late Mesozoic resulted in a high-reflection zone in the Yinchuan basin.

We obtained the information about the possible material compositions and formation timing of the high reflection zone under the Yinchuan basin so that we could propose a 

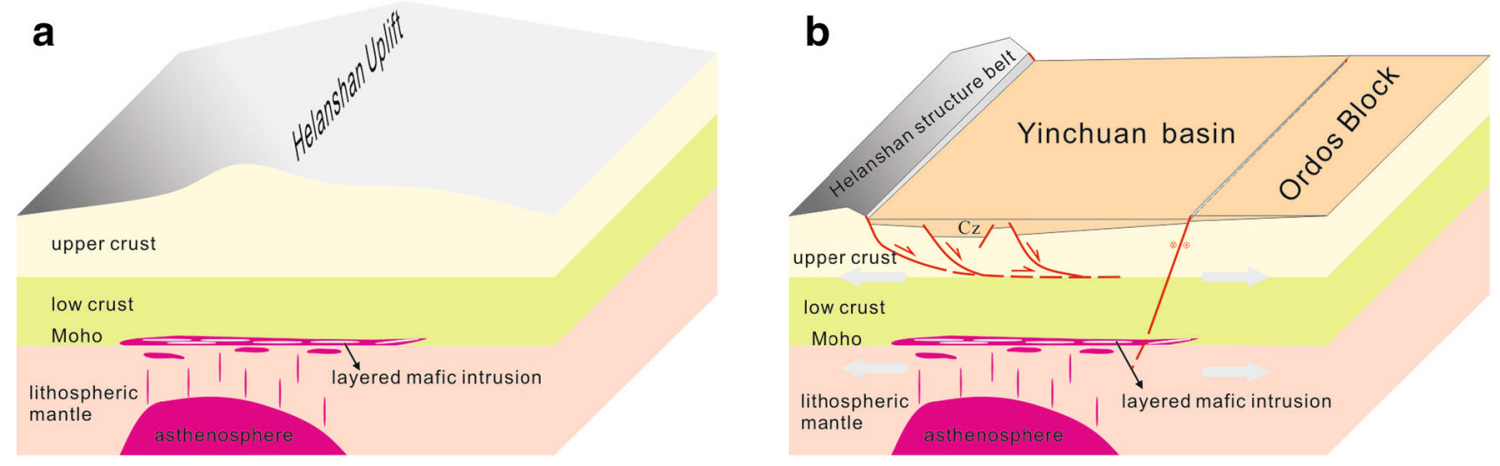

Fig. 6 a Late mesozoic magmatic underplating in the lower crust of the Yinchuan basin; b Cenozoic tectonic pattern in the Yinchuan basin

mechanism for the development of the basin at depth. In the Late Mesozoic, upwelling in the asthenosphere led to the partial melting of upper mantle, producing the ultra-basic or basic magma. Intrusion of these magmas into the lower crust in the form of sheets ultimately resulted in the highreflection zone under the Yinchuan basin (Fig. 6a). As a result of isostatic compensation, the presence of high-density material in the lower crust induced the extension of upper crust, supporting the observation of extension setting during the Late Mesozoic. During the Cenozoic, the effect of the northwestward subduction of the pacific plate and the far-field effects of the northward subduction of Indian plate under the Eurasian plate resulted in the Yinchuan basin area in extension circumstance (Huang et al. 2013; Shi et al. 2015), which promoted the evolution of the Yinchuan basin (Fig. 6b). The high-density material in the high reflection zone compensated for crustal thinning in the Yinchuan basin, resulting in the almost flattened Moho.

\section{Conclusions}

1. A $2-3.2 \mathrm{~km}$ thick high reflection zone was imaged in the lower crust near the Moho, which thinned as the sediment thickness decreased in the Yinchuan basin. Combined with other clues, we suggest that this high reflection zone formed by underplating with mantlederived magma.

2. In conflict with the generally accepted view of basin formation, we imaged a flat Moho under the Yinchuan basin. This feature was suggested to have been caused by the high-density material located in the highreflection zone compensating for crustal thinning in the Yinchuan basin. This resulted in a flat Moho, rather than the expected uplifted boundary.

Acknowledgments We thank the editors and anonymous reviewers for their critical comments and constructive suggestions. This study was financed jointly by the SinoProbe Project of China (Sinoprobe-
02-01), the National Natural Science Foundation of China (Nos. 41430213, 41274097, and 41404072), Geological Investigation Project of China Geological Survey (Nos. 1212011220260 and 12120115027101), and "Urban Active Fault Detection" of National Development and Reform Commission (No. 20041138).

Open Access This article is distributed under the terms of the Creative Commons Attribution 4.0 International License (http://crea tivecommons.org/licenses/by/4.0/), which permits unrestricted use, distribution, and reproduction in any medium, provided you give appropriate credit to the original author(s) and the source, provide a link to the Creative Commons license, and indicate if changes were made.

\section{References}

Brun JP, Gutscher MA, DEKORP-ECORS Teams (1992) Deep crustal structure of the Rhine Graben from DEKORP-ECORS seismic-reflection data: a summary. Tectonophysics 208: 139-147

Chai CZ, Liao YH, Zhang WX, Xu WJ (2001) Late Quaternary paleoearthquakes and their rupture features along the lingwu fault. Seismol Geol 23(1):15-23 (in Chinese with English abstract)

Chai CZ, Meng GK, Du P, Wang Y, Liu BJ, Shen WH, Lei QY, Liao YH, Zhao CB, Feng SY, Zhang XH, Xie XF (2006) Comprehensive multi-level exploration of buried active fault: an example of Yinchuan buried active fault. Seismol Geol 28(4):536-546 (in Chinese with English abstract)

Chen L, Cheng C, Wei ZG (2009) Seismic evidence for significant lateral variations in lithospheric thickness beneath the central and western North China Craton. Earth Planet Sci Lett 286(1):171-183

Chen L, Cheng C, Wei ZG (2010) Contrasting structural features at different boundary areas of the North China Craton and its tectonic implications. Adv Earth Sci 25:571-581 (in Chinese with English abstract)

Deemer SJ, Hurich CA (1994) The reflectivity of magmatic underplating using the layered mafic intrusion analog. Tectonophysics 232:239-255

Deng QD, Wang YP, Liao YH, Zhang WQ, Li ML (1984) Fault colluvium study and Holocene activity of Helan Mountain front fault. Chin Sci Bull 29(9):557-560 (in Chinese)

Deng QD, Cheng SP, Min W, Yang GZ, Ren DW (1999) Discussion on Cenozoic tectonics and dynamics of Ordos Block. J Geomech 5(3):13-22 (in Chinese with English abstract) 
Editorial board on "geological transect", State Seismological Bureau (EBGTSSB) (1992) Geological Transect from Fengxian Shanghai to Alashanzuoqi Inner Mongolia. Seismological Press, Beijing, pp 1-66 (in Chinese)

Fang SM, Zhao CB, Cai CZ, Liu BJ, Feng SY, Liu MJ, Lei QY, Liu H (2009) Seismic evidence of crustal structures in the Yinchuan faulted basin. Chin J Geophys 52(7):1768-1775 (in Chinese with English abstract)

Feng SY (2011) Fine crustal structure in Yinchuan basin, the seismotectonics and the Shallow Seismic Survey of Buried Active Fault. Chinese Academy of Geological Sciences, Beijing, pp 1-143 (in Chinese with English abstract)

Feng SY, Gao R, Long CX, Fang SM, Zhao CB, Kou KP, Tan YL, He HJ (2011) The compressive stress field of Yinchuan garben: deep seismic reflection profile. Chin J Geophys 54(3):692-697 (in Chinese with English abstract)

Feng SY, Liu BJ, Ji JF, He YJ, Tan YL, Li YQ (2015) The survey on fine lithospheric structure beneath Hohhot-Baotou basin by deep seismic reflection profile. Chin J Geophys 58(4):1158-1168 (in Chinese with English abstract)

Gerya TV, Burg JP (2007) Intrusion of ultramafic magmatic bodies into the continental crust: numerical simulation. Phys Earth Planet Inter 160:124-142

Hou XB, Cui HZ, Xun YL (2012) Analysis of structural style and tectonic evolution in Yinchuan basin. J Northeast Pet Univ 36(6):28-33 (in Chinese)

Hou XB, Yi KM, Lin ZK, Han XY, Chen W (2014) The study of tectonic inversion, evolution, and superposition of Yinchuan basin. Geol J China Univ 20(2):277-285 (in Chinese with English abstract)

Huang XF, Shi W, Li HQ, Chen L, Cen M (2013) Cenozoic tectonic evolution of the Yinchuan Basin: constraints from the deformation of its boundary faults. Earth Sci Front 20(4):199-210 (in Chinese with English abstract)

Huang XF, Shi W, Chen P, Li HQ (2015) Superposed deformation in the Helanshan structural belt: implications for Mesozoic intracontinental deformation of the North China plate. J Asian Earth Sci. doi:10.1016/j.jseaes.2015.05.027

Lei QY, Cai CZ, Du P, Wang Y, Meng GK (2011) Characteristics of late Quaternary activity of the Luhuatai buried fault revealed by drilling. Seismol Geol 33(3):602-614 (in Chinese with English abstract)

Lei QY, Cai CZ, Wang Y, Du P, Meng GK (2012) Activity characteristics of Xidatan buried fault in Yinchuan basin in late Quaternary. Northwest Seismol J 34(2):186-191 (in Chinese with English abstract)

Li ML, Wan ZC (1984) Characteristics of the earthquake-generating structures for magnitude 8.0 Pingluo earthquake of 1739 and the process of its preparation. Seismol Geol 6(3):23-28 (in Chinese with English abstract)

Liao YH, Cai CZ, Zhang WX, Xu WJ (2000) The active features and slip rate of Lingwu faults in late Quaternary. Earthq Res China 16(2):158-165 (in Chinese with English abstract)

Lin AM, Hu JM, Gong WB (2015) Active normal faulting and the seismogenic fault of the $1739 M \sim 8.0$ Pingluo earthquake in the intracontinental Yinchuan Graben, China. J Asian Earth. doi:10.1016/j.jseaes.2015.04.036

Liu YS, Yuan HL, Gao S, Hu ZC, Wang XC, Liu XM, Ling WL (2004) Zircon U-Pb ages of olivine pyroxenite xenolith from Hannuoba: links between the $97 \sim 158$ Ma basaltic underplating and granulite-facies metamorphism. Chin Sci Bull 49(8):790-797 (in Chinese with English abstract)

Liu JH, Zhang PZ, Zheng DW, Wan JL, Wang WT (2010) Pattern and timing of late Cenozoic rapid exhumation and uplift of the Helan Mountain, China. Sci China Earth Sci 53(3):345-355
Lv QT, Hou ZQ, Yang ZS, Shi DN (2004) Underplating in the middle-lower Yangtze valley and model of geodynamic evolution: constraints from geophysical data. Sci China Earth Sci 34(9):783-794 (in Chinese with English abstract)

Lv QT, Hou ZQ, Yang ZS, Shi DN (2005) Underplating in the middle-lower Yangtze valley and model of geodynamic evolution: constraints from geophysical data. Sci China Earth Sci 48(7):985-999

Ma HQ, Ding ZF, Chang LJ, Gao WP, Cai XH (2010) Seismic anisotropy of the upper mantle in ningxia region. Acta Seismol Sin 32(5):507-516 (in Chinese with English abstract)

McCarthy J, Parsons T (1994) Insights into the kinematic Cenozoic evolution of the Basin and Range-Colorado Plateau transition from coincident seismic-refraction and reflection data. Geol Soc Am Bull 106:747-759

McGuire AV (1994) Southern basin and Range province crust-mantle boundary-evidence from gabbroic xenoliths, Wikieup, Arizona. J Geophys Res 99:24263-24273

McKenzie D (1978) Some remarks on the development of sedimentary basins. Earth Planet Sci Lett 40:25-32

Nielsen CA, Thybo H (2009) No Moho uplift below the Baikal Rift zone: evidence from a seismic refraction profile across southern Lake Baikal. J Geophys Res 114:B08306. doi:10.1029/2008 JB005828

Olesen KH (1995) Continental Rifts: Evolution, Structure, Tectonics. Elsevier, Amsterdam, pp 1-26

Petroleum Geological Compile Group of Changqing Oil Field (PGCGCOF) (1992) Petroleum Geology of China, 12th edn. Petroleum Industry Press, Beijing, pp 362-371

Ruppel C (1995) Extensional processes in continental lithosphere. J Geophys Res B 100:24187-24215

Shi W, Dong SW, Liu Y, Hu JM, Chen XH, Chen P (2015) Cenozoic tectonic evolution of the South Ningxia region, northeastern Tibetan Plateau inferred from new structural investigations and fault kinematic analyses. Tectonophysics 649:139-164

Thybo H, Artemieva IM (2013) Moho and magmatic underplating in continental lithosphere. Tectonophysics 609:605-619

Thybo H, Nielsen CA (2009) Magma-compensated crustal thinning in continental rift zones. Nature 457:873-876

Thybo H, Maguire PKH, Birt CS, Perchuc E (2000) Seismic reflectivity and magmatic underplating beneath the Kenya Rift. Geophys Res Lett 27(17):2745-2748

Wang HY, Gao R, Lu ZW, Li QS, Kuang ZY, Liu JK, Hou HS, Feng SY, Xiong XS, Li WH, Deng G (2010) Fine structure of the continental lithosphere circle revealed by deep seismic reflection profile. Acta Geol Sin 84(6):818-839 (in Chinese with English abstract)

Wang WT, Zhang PZ, Kirby E, Wang LH, Zhang GL, Zheng DW, Chai CZ (2011) A revised chronology for tertiary sedimentation in the sikouzi basin: implications for the tectonic evolution of the northeastern corner of the Tibetan Plateau. Tectonophysics 505(1):100-114

Yang WC, Wang JY (2002) Geophysical evidences of magmatic underplating in the Sulu area, East China. Acta Geol Sin 76(2):173-179 (in Chinese with English abstract)

Yang ZX, Duan YH, Wang FY, Zhao JR, Pan SZ, Li L (2009) Tomographic determination of the deep earthquake faults in Yinchuan basin by using three-dimensional seismic transmission technology. Chin J Geophys 52(8):2026-2034 (in Chinese with English abstract)

Zhang WQ, Liao YH, Pan ZS, Song FM (1982) On the piedmont scarp in diluvial fan of Mt. helanshan. Seismol Geol 4(2):32-34 (in Chinese)

Zhang YQ, Mercier JL, Vergely P (1998) Extension in the graben systems around the Ordos (China), and its contribution to the 
extrusion tectonics of South China with respect to GobiMongolia. Tectonophysics 285:41-75

Zhang SH, Liu TY, Gu HM, Deng RL (2003a) A synthetic geophysics interpretation of the igneous rocks in Bayanhaote Basin. Geophys Geochem Explor 27(5):383-386 (in Chinese with English abstract)

Zhang YQ, Ma YS, Yang N (2003b) Cenozoic extensional stress evolution in North China. J Geodyn 36(5):591-613

Zhang YQ, Liao CZ, Shi W, Hu B (2006) Neotectonic evolution of the peripheral zones of the ordos basin and geodynamic setting. Geol J China Univ 12(3):285-297 (in Chinese with English abstract)
Zhao HG, Liu CY, Wang F, Wang JQ, Li Q, Yao YM (2007) Uplift timing and evolution of Helan Mountain. Sci China Earth Sci 37:185-192 (in Chinese)

Zhou TX, Wang L, Cao MZ (1985) Morphotectonic patterns of Ningxia Hui Autonomous Region and its formation and evolution. Geogr J 40(3):215-223 (in Chinese with English abstract) 